\title{
ナスすすかび病の発生推移と発生初期の薬剤防除
}

\author{
山口純一郎・御厨 初子・松崎 正文 \\ (佐賀県農業試験研究センター)
}

\section{Change in disease incidence by leaf mold on eggplant due to Mycovellosiella nattrassii Deighton, and the effect of chemical control during early development.} Junichirou Yamaguchi, Hatsuko Mikuriya and Masafumi Matsuzaki (Saga Prefectural Agricultural Research Center, Kawasoe, Saga 840-2205, Japan)

During the early development of leaf mold on eggplants caused by Mycovellosiella nattrassii, the proportion of diseased leaves towards the outer part of the greenhouse was higher than in the center. On diseased leaves, many secondary lesions appeared 20-30 days after the first lesions At the same time, the first lesion appeared on other leaves. As a result, there was an increase in the proportion of diseased leaves. Chemical control carried out twice during early development reduced the proportion of diseased leaves to less than $5 \%$ after 45 days.

Key words : chemical control, eggplant, leaf mold, Mycovellosiella nattrassii

\section{緒言}

ナスすすかび病は，葉の裏面に白〜灰褐色のすす状の 斑点を形成し, 病斑が多数生じると葉全体が黄化して落 葉し被害をもたらす。本病の病原菌 Mycovellosiella nattrassii Deighton はわが国に扔いては，1971年に福岡 県の加温促成栽培ナス（佐藤ら，1973）で，翋年の1972 年には高知県で確認され（音藤ら、1974），その後現在 は西日本を中心に，各地の施設栽培を主体に発生してい る。本病は蔓延すると薬郕防除効果が上がりにくく，特 にDMI 耐性菌が発生しているほ場においては，多発生
条件での DMI の防除効果は少発生時に比較して低くな る（山口ら，1999）。したがって，効果的な防除を行う には，ほ場における本病の発病とその後の進展状況を把 握することが重要である。そこで本試験では，ほ湯にお ける本病の発生推移を調查し, 初発生時防除の有効性を 検討したので，その概要を報告する。

\section{材料および方法}

初発生時の発生分布および発生推移調查 佐賀郡川副 町の佐賀県農業試験研究センター内の施設栽培ナス（品 種：筑陽, 加温促成栽培, ポリエチレンフィルム被覆屋

第1表 ナスすすかび病に対する各薬剤散布体系

\begin{tabular}{|c|c|c|c|c|}
\hline \multirow{2}{*}{ 試験区 } & \multicolumn{4}{|c|}{ 薬剂 散 布 年 月 日 } \\
\hline & 1999.12 .21 & 12.28 & 2000.1 .17 & 2.4 \\
\hline (1)体系防除区 & アゾキシスロビン水和郕 & $\begin{array}{c}\text { トリフルミゾール水和剤 } \\
3.000 \text { 倍 }\end{array}$ & $\begin{array}{l}\text { イミノクタジンアルベ } \\
\text { シル酸壏水和用 } \\
3,000 \text { 倍 }\end{array}$ & $\begin{array}{c}\text { アゾキシスロビン水和剛 } \\
2,000 \text { 倍 }\end{array}$ \\
\hline (2) DMI 連続散布区 & $\begin{array}{c}\text { トリフルミゾール水和㓱 } \\
3,000 \text { 倍 }\end{array}$ & $\begin{array}{c}\text { フェナリモル水和剛 } \\
6.000 \text { 倍 }\end{array}$ & $\begin{array}{c}\text { ミクロブタニル水和剤 } \\
4,000 \text { 倍 }\end{array}$ & $\begin{array}{c}\text { トリフルミゾール水和剤 } \\
3,000 \text { 倍 }\end{array}$ \\
\hline $\begin{array}{l}\text { (3)初期 } 2 \text { 回（AZ 剂1) } \\
\text { + DMI）散布区 }\end{array}$ & $\begin{array}{c}\text { アゾキシスロビン水和剂 } \\
2,000 \text { 倍 }\end{array}$ & $\begin{array}{c}\text { トリフルミゾール水和剤 } \\
3,000 \text { 倍 }\end{array}$ & - & - \\
\hline $\begin{array}{l}\text { (4)初期 } 2 \text { 回（AZ 郕） } \\
\text { 散布区 }\end{array}$ & $\begin{array}{c}\text { アゾキシスロビン水和荗 } \\
2,000 \text { 倍 }\end{array}$ & 2,000 倍 & - & \\
\hline (5)無散布 & - & - & - & - \\
\hline
\end{tabular}

${ }^{11} \mathrm{AZ}$ 剂：アゾキシスロビン水和剂 
根型鉄骨ハウス， $20 \mathrm{~m} \times 18 \mathrm{~m} ）$ 戋場において，本病自然 発生条件下で調査を行った。初発生時の発生分布は, 本 病が初発生した1999年12月17日に実施し, 施設の東半分 に定植されたナス 4 列（A～D D ) の各20株を 5 株ずつ 4 区に分け，さらに東西（a， b ）に区分して，その中の 任意の200葉について発病の有無を調査し, 発病葉率を 算出した。発生推移は, 次項の薬剤防除試験の(5)無散布 区（ 1 区 5 株, 3 反復）において調査した。任意の100葉 の発病の有無および下記基準による発病程度を, 1999年 12月 17 日から 2000 年 3 月 6 日まで約10日間隔で調査し, 発病葉率および発病度を算出した。

発病度 $=\sum($ 発病程度の指数 $\times$ 葉数 $) /(4 \times$ 調査葉数 $)$

発病程度 (数值は発病指数)

0 : 発病を認めない, 1 : 病斑面積が葉面積の $5 \%$ 未満, 2 : 病斑面積が葉面積の $5 \sim 24 \%, 3$ : 病斑面積が葉面積 の25〜49\%，4：病斑面積が葉面積の50\%以上

また，施設内中央部にデーターロガーを設置し，調査 期間の施設内の相対湿度および温度を測定した。

薬剤防除試験 発生推移調査と同一ほ場において, 1 区 5 株 $(1.5 \mathrm{~m} \times 6 \mathrm{~m})$ の 3 反復で試験を行った。試験 区は第 1 表に示すとおり，(1)体系防除区，(2) DMI の連 続散布区, (3)アゾキシストロビン水和剤とトリフルミ ゾール水和剤の発生初期 2 回散布区, (4)アゾキシストロ ビン水和剤発生初期 2 回散布区および(5)無散布区を設置 した。所定濃度に調整したそれぞれの薬剤 $300 \ell / 10 \mathrm{a}$ を あて背負式動力噴霧器で散布した。散布日は初発生時の 1999年12月21日とその 7 日後の12月28日に, さらに(3)お よび(4)区の3，4回目の追加散布は，2000年 1 月17日およ び 2 月 4 日に行った。なお, 管理は農業試験研究セン ター慣行で, 摘葉も随時行った。

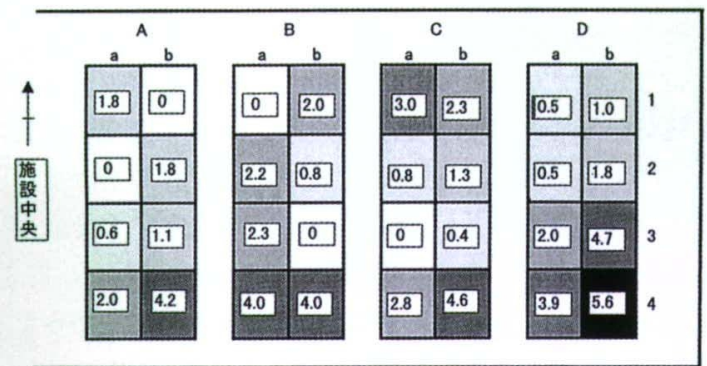

発病葉率 $5.0 \%$ 以上 [7 1.9 1.0\%以上

$4.9 \sim 4.0 \%$ 以上 $3.9 \sim 3.0 \%$ 以 图 2.9 2.0\%以上

第 1 図 初発生時のナスすすかび病の （1999年12月17日）
結

果

初発生時の発生分布 初発生時における発生分布を 第 1 図に示した。発病葉率 $5 \%$ 台の区は南東側の Db4, 4\%台が南側の $\mathrm{Ab}-4, \mathrm{Ba}-4, \mathrm{Bb}-4, \mathrm{Cb}-4$ およ び東側の $\mathrm{Db}-3$ であり, 南側および東側の施設周辺部 で高い傾向にあった。一方, 中央部の $\mathrm{A} \sim \mathrm{C}-2 \sim 3$ 区 は，すべて $3 \%$ 未満で低かった。

ほ場における発生推移 初発生後の発病葉率の推移を 程度別に第 2 表に示した。12月17日に認められた発病葉 は病斑数 1 ～個/葉で, すべて発病程度が 1 であり, 1 月 4 日まで発病葉率, 発病度のいずれも停滞していた。 しかし，第 2 図に示すとおり，程度 1 であった発病葉の 1 次病斑は 1 月 14 日には中心部が灰色に変色した病斑と

第 2 表 ナスすすかび病初発生後の発病葉率の推移

\begin{tabular}{rrrrrr}
\hline \multirow{2}{*}{ 調查年月日 } & $\begin{array}{c}\text { 発病葉率 } \\
(\%)\end{array}$ & \multicolumn{4}{c}{ 程度別発病葉率 $(\%)$} \\
\cline { 3 - 6 } & \multicolumn{1}{c}{1} & \multicolumn{1}{c}{2} & \multicolumn{1}{c}{3} & \multicolumn{1}{c}{4} \\
\hline 1999.12 .17 & 2.0 & 2.0 & 0 & 0 & 0 \\
2000.1 .4 & 3.1 & 3.1 & 0 & 0 & 0 \\
14 & 17.0 & 16.2 & 0.8 & 0 & 0 \\
24 & 21.5 & 14.7 & 4.9 & 1.7 & 0.2 \\
2.4 & 35.9 & 15.3 & 9.4 & 7.5 & 3.7 \\
14 & 36.0 & 15.3 & 11.3 & 6.1 & 3.3 \\
24 & 45.8 & 21.0 & 11.5 & 7.7 & 5.6 \\
3.6 & 48.0 & 18.4 & 11.5 & 10.1 & 8.0 \\
\hline
\end{tabular}

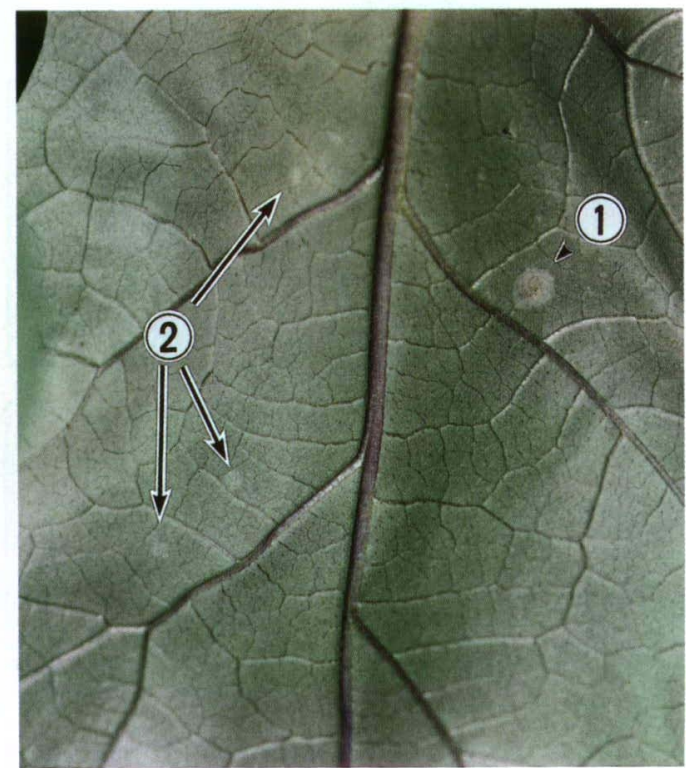

第 2 図 ナスすすかび病の 1 次および 2 次病斑 (2000年 1 月 24 日)

(1)：1次病斑, (2)：2 次病斑 
なり，さらに白色の初期の 2 次病斑が形成されはじめ, 程度 2 以上の発病葉に進展した。また同時に, 新たに病 斑を形成した程度 1 の発病葉も認められ, 発病葉の増加 に伴い発病葉率が急増した。その後,このような発病葉 率の急激な增加は，2月 4 日と 24 日に認められた。また， 調查期間の相対湿度は第 3 図に示すとおり 80 90\%前後, 温度は $18^{\circ} \mathrm{C}$ 前後で推移した。

初発生時からの薬剤防除試験 各薬剤散布区に抢ける 発生推移を第 4 図に示した。すなわち, 各種系統薬片の 体系散布区である(1)区は調査期間中，発病をほとんど認 めず，ほぼ完全な防除効果を示した。DMIの連続散布 の(2)区に扔いても，3月 6 日に進展がみられたものの発

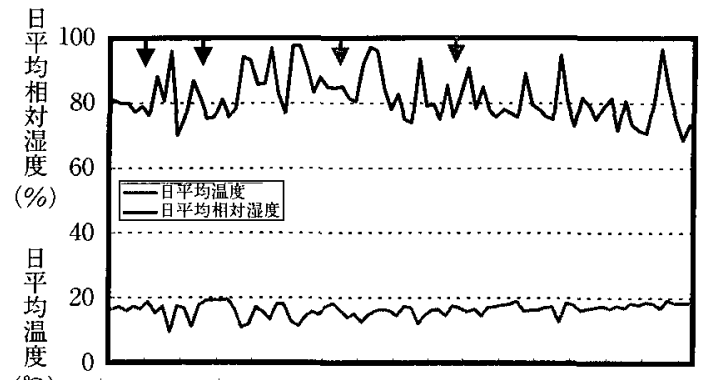

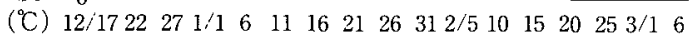
†(1)(2)(3)(4)区薬用散布 \(1)(2)区薬郕散布

第 3 図＼cjkstart試験期間にお打る施設内の日平均 相対湿度掞よび温度の推移
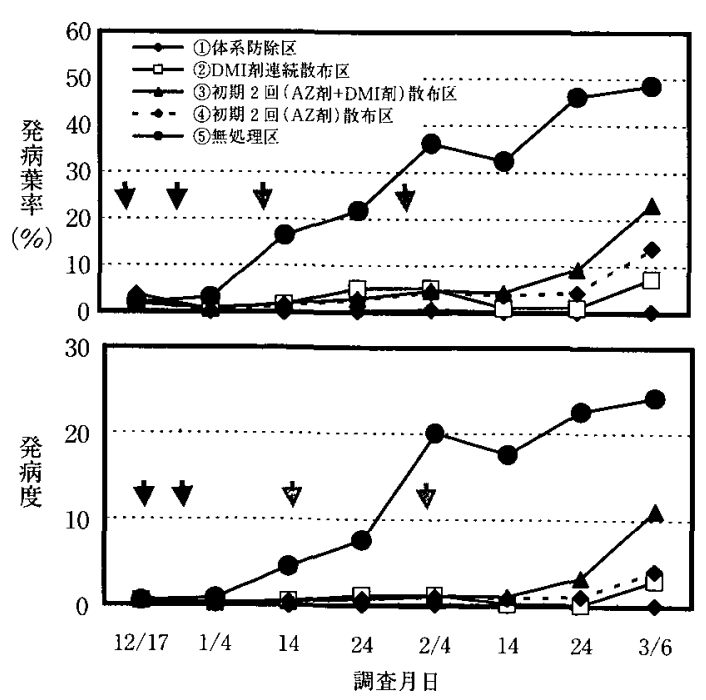

\(1)(2)(3)(4)区薬剤散布 †(1)(2)区薬剂散布

第 4 図 各薬荗散布区におけるナスすすかび病の発 生推移
病葉率を $10 \%$ 以下に抑え，高い効果を示した。アゾキシ ストロビン水和剤とトリフルミゾール剤の発生初期 2 回 散布の(3)区およびアゾキシストロビン水和刻発生初期 2 回散布(4)区は，3月6日に進展したものの，最終散布か ら45日後の 2 月 14 日まで発病葉率 $5 \%$ 以下に抑える効果 を示した。(3)区と(4)区を比較すると，(4)区の効果が高 かった。

\section{考察}

本試験のほ場は，每作本病が発生し，特に施設の南東 側に扔いて発生が多い。本ほ場では，作期毎の被覆資材 の更新は行われないため, 南東部での発生が多いのは, 一次伝染源である資材に付着した病原菌量が多いこと （山口ら，1999）や中央部よりやや高めに推移する周辺 部の相対湿度の影響が考えられる。したがって, 前作で 発生が多く認められた地点近くの施設内の周辺部の株を 観察することにより，初発生が早く確認される可能性が 高く，初発生の把握に有効と思われる。

また，発病葉は初発生時などの菌密度が低い条件下で は，まず 1 数個の 1 次病斑が形成され，20〜30日の停 滞期間を経た後に数 10 個の 2 次病斑が形成されて発病程 度が高まることが明かとなった。さらに，2次病班形成 と同時期に，別の葉においては新たな 1 次病斑を形成す ることで発病葉が急激に増加していくことも判明した。 本病の接種試験において，潜伏期間は相対湿度が95\%以 上で14日間，80\%で23〜40日であることが明かとなって いる（山口，1998）。本試験での施設内ほ場における日 平均相対湿度は約80～90\%台で推移しており，これらの 発病停滞期間は本病菌の潜伏期間によるものと考えられ る。

薬荗防除試験注場に扔いて，前作の6月に採取した本 病菌のトリフルミゾール剤に対する $\mathrm{EC}_{50}$ 值を調查したと ころ, 5 菌株平均で $1.9 \mu \mathrm{g} / \mathrm{ml}$ であった。したがって, 本薬片防除試験は DMI に対し中程度の耐性菌が発生し ている条件であったが, DMIを連続散布した(2)区は各種 系統薬剂体系の11区には劣るものの高い防除効果を示し た。DMI 耐性菌の接種試験において，DMI の治療効果 はほとんど期待できないが，予防的に使用すると発病遅 延効果が認められている（山口ら，1999）。したがって， DMI 耐性菌発生ほ場においても, DMI は初発生時から予 防的に使用すると，有効であることが確認された。

(1)区は初発生時の 2 回防除に加之て, 追加防除を行っ たが，その追加防除日は予防散布の観点から，無散布区 の発病葉率および発病度が急増した直後で分生子の飛散 が多いと予想される異雨天が続いた後の晴天日に行った 
ため(山口ら，2000），発生がほとんど認められず高い 効果を示した。しかしながら，同様に初期防除のみを 行った(3)区では, 最終散布から45日後まで初発生程度に 発病を抑元ており，追加防除は 2 月以降まで延期するこ とが可能と考えられた。さらに，本病に対し効果の高い アゾキシストロビン水和剤を 2 回初期防除に使用した(4) 区は，(3区より高い効果が認められ，初期防除の徹底が 有效であることが示された。

以上のことから, 例年発生が多い地点に近い施設周辺 部の株を調查し, 初発生を早く確認し, すみやかに楽剤 防除を行うことが, 本病の効果的な防除対策となること が確認された。

\section{引用文 献}

斉藤 正・山本般・含田宗良・中田拓也（1974） Mycovellosiella 属菌によるナスの新病害. 高知農林
研報 $6: 1-6$.

佐藤 徹・松本省平（1973）八ウス栽培の新しい病害に ついて. 九病虫研会報 $19: 28-30$.

山口純一郎 (1998) ナスすすかび病の生態と防除. 日本 植物病理学会九州部会第23回シンポジウム講演集: pp. $39-56$.

山口純一郎・㮐田 稳・松崎正文 (1999) ナスすすかび 病菌分生子の生存と温度との関係。九病虫研会報 45： $27-29$.

山口純一郎·御㕌初子・松崎正文 (1999) DMI 系薬剂耐 性ナスすすかび病菌の発生と対策. 日植病報 $65: 644$ (講要).

山口純一郎・稲田 稳・松崎正文 (2000) ナスすすかび 病菌分生子の離脱と飛散. 日植病報 $66: 5-11$.

（2000年 4 月30日 受領） 